\title{
PEMBINAAN NARAPIDANA DI RUMAH TAHANAN SUMENEP
}

\author{
ZAINURI \\ Fakultas Hukum, Universitas Wiraraja Sumenep \\ gprzainuri@yahoo.co.id
}

\begin{abstract}
ABSTRAK
Sistem pembinaan bagi narapidana telah berubah dari sistem kepenjaraan menjadi sistem pemasyarakatan, perusahaan dari rumah penjara menjadi Lembaga Pemasyarakatan, bukan semata-mata hanya secara fisik merubah atau mendirikan bangunannya saja, melainkan yang lebih penting menerapkan konsep pemasyarakatan. Upaya pendidikan untuk semua lapisan masyarakat dari usia dini sampai lanjut usia, termasuk kecakapan hidup bagi narapidana yang sedang menjalani hukuman lembaga permasyarakatan.

Peningkatan Pembinaan Narapidana. Manfaat yang diharapkan dari penelitian ini agar dapat memberikan Masukan bagi pihak Lembaga Pemasyarakatan Kab. Sumenep untuk mengevaluasi pelaksanaan sistem pemasyarakatan Lembaga Pemasyarakatan Berbeda dengan berpedoman Undang-Undang Nomor 12 Tahun 1995 tentang Pemasyarakatan sehingga mantan narapidana akan benar-benar menyadari kesalahannya yang pada akhirnya akan menjadi anggota masyarakat berguna bagi agama, bangsa, dan negara. Masukan bagi pihak Lembaga Pemasyarakatan Kab. Sumenep dan instansi terkait untuk dapat mencari upaya penyelesaian dalam menghadapi kendala dalam pelaksanaan sistem pemasyarakatan di Lembaga Pemasyarakatan Kab. Sumenep.
\end{abstract}

Kata Kunci : Peningkatan, Pembinaan, Narapidana.

\section{A. PENDAHULUAN}

Lembaga Pemasyarakatan (disingkat LP atau Lapas) adalah tempat tuntuk melakukan pembinaan terhadap narapidana dan anak didik pemasyarakatan di Indonesia, tempat tersebut disebut dengan istilah penjara.

$$
\text { Lembaga Pemasyarakatan }
$$

merupakan unit pelaksana teknis di bawah

Direktorat Jenderal Pemasyarakatan

Kementerian Hukum dan Hak Asasi Manusia (dahulu Depertamen Kehakiman). Penghuni Lembaga Pemasyarakatan bisa narapidana (Napi) atau warga Binaan Pemasyarakatan tahanan (WBP) bisa juga yang statusnya masih tahanan, maksudnya yang statusnya masih berada dalam proses peradilan dan belum ditentukan bersalah atau tidak oleh hakim. Pegawai Negeri Sipil yang menangani pembinaan narapidana dan tahanan di lembaga pemasyarakatan di sebut dengan petugas pemasyarakatan, atau dahulu lebih dikenal dengan istilah sipir penjara.

Konsep pemasyarakatan pertama kali digagas oleh Menteri Kehakiman Dr. Sahardjo pada tahun 1964, dimana disebutkan bahwa tugas jawatan kepenjaraan bukan hanya melaksanakan hukuman, namun tugas yang jauh lebih berat adalah mengembalikan orang-orang yang dijatuhi pidana ke dalam masyarakat. Lembaga pemasyarakatan yang tadinya disebut penjara, bukan saja dihuni oleh 
pencuri, perampok, penipu, pembunuh atau perkosaan, tetapi juga ditempati oleh pemakai, kurir, pengedar dan Bandar narkoba, serta penjudi dan Bandar judi, beragam lainnya seperti Korupsi dan lainlain.

Sistem pembinaan bagi narapidana telah berubah dari sistem kepenjaraan menjadi sistem pemasyarakatan, perusahaan dari rumah penjara menjadi Lembaga Pemasyarakatan, bukan sematamata hanya secara fisik merubah atau mendirikan bangunannya saja, melainkan yang lebih penting menerapkan konsep pemasyarakatan. Upaya pendidikan untuk semua lapisan masyarakat dari usia dini sampai lanjut usia, termasuk kecakapan hidup bagi narapidana yang sedang menjalani hukuman lembaga permasyarakatan.

Pengembangan pendidikan kecakapan hidup merupakan tugas dan wewenangan pendidikan luar sekolah sebagai upaya pengembangan sumber daya manusia yang dirasakan kepada sumber daya manusia yang didasarkan kepada sumber daya manusia pengembangan pendidikan tersebut sangat penting bagi narapidana, karena jumlah narapidana di lembaga pemasyarakatan. Khususnya di lembaga pemaasyarakatan kelas II B Kab. Sumenep.

\footnotetext{
Narapidana adalah orang yang telah melanggar norma kehidupan, mereka tidak tahan kondisi kehidupan
}

yang serba sulit sehingga menimbulkan sifat frustasi, kehilangan pekerjaan dan masalah-masalah lain seperti tidak terpenuhi kebutuhan dasar (sandang, pangan dan papan) di satu pihak, dan di pihak lain tidak sedikit pula narapidana yang berasal dari lapisan masyarakat yang tergolong mampu dari segi ekonomi bahkan dari kalangan elit, seperti pengusaha, politikus dan birokrat. Sehingga seseorang nekat melakukan perkosaan terhadap korbannya karena telah memaksa seorang wanita untuk melakukan hubungan suami istri di luar pernikahan yang sah tanpa keinginan wanita yang jadi korban perkosaan tersebut, membuat lembaga pemasyarakatan kelas II B Kab. Sumenep dituntut berperan aktif dalam upaya pembinaan narapidana agar kembali ke jalan yang benar dan diterima oleh Masyarakat, sehingga tidak lagi melakukan/mengulangi kejahatan.

Seorang narapidana perkosaan untuk dapat diterima hidup di tengah-tengah masyrakat harus mampu menyesuaikan dan membuktikan bahwa dirinya benarbenar sadar, insaf dan menunjukkan sikap serta perilaku yang baik. Untuk mengatasi dan mengantarkan narapidana ke jalan yang benar,maka pendidikan agama Islam merupakan peran sangat penting dan sangat menentukan bagi terbentuknya manusia yang beriman dan bertakwa kepada Allah SWT. Serta mampu mengembangkan kecakapan hidupnya, 
sebagai modal dalam upaya mengawali hidup baru di tengah masyarakat.

Permasalahan yang akan dibahas pada penelitian ini, yaitu : Bagaimana Upaya Peningkatan Pembinaan Narapidana di lembaga pemasyarakatan?

Tujuan dalam penelitian ini untuk meningkatkan pembinaaan narapidana di lembaga pemasyarakatan.

Metode penelitian yang digunakan dalam penelititan ini yaitu, yuridis normatif adalah menelaah norma-norma, kaidah-kaidah, dan aturan-aturan yang berlaku seperti hukum positif yang berkaitan dengan penalitian yang diangkat.

\section{B. PEMBAHASAN}

Penjatuhan hukuman terhadap sipelaku tindak pidana (offender) bukanlah semata-mata sebagai suatu tindakan balasan atas kejahatan yang dilakukan oleh sipelaku, Filosofi pembinaan pelanggar hukum yang dianut oleh Indonesia adalah mengintegrasikan kembali pelaku pelanggar hukum ke masyarakat, atau lebih dikenal sebagai pemasyarakatan. Akan tetapi dalam realitas, mantan narapidana secara sistematis justru dihambat untuk dapat berintegrasi kembali dalam kehidupan alamiah di masyarakat. Banyak peraturan-perundangan dan kebijakan yang dibuat justru untuk menghambat terintegrasinya kembali mantan napi dengan masyarakat. Dengan demikian maka filosofi pemasyarakatan napi hanya sekedar slogan kosong, yang dalam realitas menghasilkan pelaku pelanggar ulang, yang bolak-balik kembali ke bangunan penjara.Masyarakat dan struktur sosial (politik) telah melakukan stigmatisasi mantan napi yang sesungguhnya tidak selaras dengan filosofi pemasyarakatan napi.

Pada dasarnya terdapat tiga pokok pemikiran tentang tujuan yang ingin di capai dengan suatu pemidanaa yaitu: a. untuk memperbaiki pribadi dari penjahatnya itu sendiri b. untuk membuat orang menjadi jera untuk melakukan kejahatan-kejahatan dan c.untuk membuat penjahat-penjahat tertentu menjadi tidak mampu untuk melakukan kejahatankejahatan yang lain, yakni penjahatpenjahat yang dengan cara lain sudah tidak dapat diperbaiki lagi. Karena kejahatan merupakan bagian tak terpisahkan dari kehidupan manusia di dunia.Segala aktifitas manusia baik politik, sosial dan ekonomi dapat menjadi kausa kejahatan. Sehingga keberadaan kejahatan tidak perlu disesali, tapi harus dicari upaya bagaimana cara menanganinya. Berusaha menekan kualitas dan kuantitas nya serendah mungkin, maksimal sesuai dengan situasi dan kondisi yang ada. Penanggulangan kejahatan melalui hukum pidana, merupakan kegiatan yang didahului dengan penentuan tindak pidana (Kriminalisasi) dan penentuan sanksi yang dapat dijatuhkan kepada pelaku (pelaku 
kejahatan dan pelanggaran) (Hs. Harsono, 1995:35).

Sanksi dalam hukum pidana merupakan derita yang harus diterima sebagai imbalan dari perbuatan nya yang telah merugikan orang lain atau masyarakat. Akan tetapi kenyataannya si terpidana setelah menjalani hukuman penjara misalnya, bukan jera, tapi malah mengulangi tindak pidana (resedivis).Maka dalam hal ini perlu dipertanyakan efektifitas pemidanaan dimaksud.Pidana dan sistem pemidanaan sangat mempunyai peranan penting dalam mempertahankan pidana materiil yang pada dasarnya bertujuan untuk menciptakan keamanan dan ketertiban ditengah-tengah pergaulan masyarakat (Muladi, 1986:56).

Pembinaan narapidana ini di Indonesia diterapkan dengan sistem yang dinamakan dengan sistem pemasyarakatan, sistem pemasyarakatan telah dicetuskan dan diaplikasikan sejaktahun 1964, namun pengaturan mengenai sistem tersebut secara sistematisdalam bentuk undangundang dan perangkat aturan pendukungnya barudapat diwujudkan pada tahun 1995, melalui Undang-Undang Nomor 12 Tahun 1995 tentang Pemasyarakatan. Mengenai tujuan sistem pemasyarakatan, dalam Pasal 2 undangundang tersebut ditegaskan, bahwa: "Sistem pemasyarakatan diselenggarakan dalam rangka membentuk warga binaan pemasyarakatan agar menjadi manusiaseutuhnya, menyadari kesalahan, memperbaiki diri dan tidak mengulangtindak pidana sehingga dapat diterima kembali oleh lingkungan masyarakat,dapat aktif berperan dalam pembangunan, dan dapat hidup secara wajarsebagai warga yang baik dan bertanggung jawab".

Mengenai Pola yang akan diterapkan dalam pembinaan narapida ini di Indonesia diatur dalam keputusan menteri kehakiman Republik Indonesia Nomor : M. 02-PK.04.10 tahun 1990 tentang pola pembinaan narapidana atau tahanan, didalam BAB I alinea kedua Kepmen ini sudah dilihatkan arahan yang hendak dicapai dalam pembinaan narapidana dilembaga pemasyarakatan, dijelaskan bahwa : "Secara umum dapatlah dikatakan bahwa pembinaan dan bimbingan pemasyarakatan haruslah ditingkatkan melalui pendekatan pembinaan mental (agama, Pancasila dan sebagainya) meliputi pemulihan harga diri sebagai pribadi maupun sebagai warganegara yang meyakini dirinya masih memiliki potensi produktif bagi pembangunan bangsa dan oleh karena itu mereka dididik (dilatih) juga untuk menguasai ketrampilan tertentu guna dapat hidup mandiri dan berguna bagi pembangunan. lni berarti, bahwa pembinaan dan bimbingan yangdiberikan mencakup bidang mental dan ketrampilan". 
Dengan bekal mental dan ketrampilan yang mereka miliki, diharapkan mereka dapat berhasil mengintegrasikan dirinya di dalam masyarakat. Semua usaha ini dilakukan dengan berencana dan sistematis agar selama mereka dalam pembinaan dapat bertobat menyadari kesalahannya dan bertekad untuk menjadi manusia yang berguna bagi masyarakat, negara dan bangsa.

Sedangkan kenyataan yang ada didalam masyarakat seseorang narapidana sekali saja dia dipidana karena melakukan tindak pidana tertentu, lalu ia di masukan ke suatu lembaga pemesyarakatan untuk beberapa waktu yang telah di tentukan oleh undang-undang, maka yang terjadi di masyarakat dia akan selalu di cap sebagai seorang penjahat, dalam sistem penerimaan tenaga kerja misalnya, sudah lazim dijadikan sebagai salah satu syarat untuk memperoleh pekerjaan, tidak pernah melakukan suatu tindak pidana, sehingga walaupun dia bebas dari suatu lembaga pemasyarakatan dengan kepribadian yang baik, begitu juga memperoleh keterampilan dibidang pekerjaan tetentu, namun kondisi sosiologis dimasyarakat yang demikian, juga akan membuat narapidana mau tidak mau akan mengulangi lagi kejahatannya, karena faktanya juga tidak akan mendapatkan penerimaan yang layak dari masyarakat (Kurtines dan William M. 1992).
Upaya Peningkatan Pembinaan Narapidana dengan memberikan pemahaman warga binaan Rutan Kab. Sumenep agar saling memperhatikan Rule of Law pada hakekatnya adalah memposisikan hukum sebagai landasan bertindak dari seluruh elemen bangsa dalam sebuah negara. Rule of Law dapat dilakasanakan dengan menjunjung tinggi Hak Asasi Manusia karena salah satu ciri dari Rule of Law (negara hukum) adalah terlindunginya Hak Asasi Manusia di negara yang bersangkutan.

Pemidanaan merupakan suatu proses. Sebelum proses ini berjalan, peranan Hakim penting sekali. la mengkonkritkan sanksi pidana yang terdapat dalam suatu peraturan dengan menjatuhkan pidana kepada terdakwa dalam kasus tertentu. Sistem pemidanaan yang dianut dalam KUHP bersifat alternatif artinya hakim hanya boleh menjatuhkan satu jenis pidana pokok terhadap terdakwa yang terbukti melakukan tindak pidana sebagaimana yang didakwakan kepadanya, misalnya pidana penjara digabungkan dengan pidana kurungan atau denda. Dengan demikian tidak dikenal adanya kumulasi sanksi pidana pokok.

Berbeda halnya dengan sistem pemidanaan yang dianut dalam Tindak Pidana khusus, seperti Korupsi dan lain sebagai. Tindak pidana khusus menganut kumulatif (kumulasi) dimana hakim dapat 
menjatuhkan dua jenis pidana pokok sekaligus terhadap terdakwa yang terbukti melakukan tindak pidana sebagaimana yang didakwakan kepadanya, misalnya pidana penjara dengan pidana denda, pidana kurungan dengan pidana denda.

Kalau mengikuti dalil evolusi penghukuman dari Durkheim tersebut, dapat dikatakan bahwa perlakuan tidak adil terhadap mantan napi menunjukkan bahwa masyarakat dan kekuasaan pusat (struktur sosial poilitik) yang cenderung absolut merupakan ciri masyarakat primitif. Padahal sesungguhnya ciri umum masyarakat Indonesia yang merupakan bangsa timur, dalam menyikapi pelanggaran hukum pidana cenderung mencari solusi perdamaian atau pemulihan hubungan antara pelaku dengan korban dan masyarakat. Pelanggaran hukum pidana dilihat tidak semata-mata sebagai konflik antar pribadi (micro cosmos), tetapi merupakan keadaan yang dapat mengganggu kesetablian alam semesta (macro cosmos). Oleh karena itu ketidak seimbangan yang dihasilkan harus disikapi dengan mengembalikan kesetabilan hubungan para pihak yang berkonflik.

Filosofi penghukuman bangsabangsa timur ini telah digali oleh ilmuwan barat John Braithwaite menjadi konsep restorative justice. Restorative justice adalah cara penyelesaian konflik pidana melalui cara-cara informal yang dilakukan oleh komunitas dengan tujuan memulihkan hubungan antara pelaku dengan korbannya dan yang direstui masyarakat, dengan tetap menyatakan bahwa pelanggaran hukum adalah tindakan yang tidak benar. Melalui mekanisme ini ada upacara untuk menyatakan bahwa pelanggaran hukum adalah salah, tetapi melalui proses restorasi, pelanggar hukum diterima kembali menjadi warga masyarakat.

Masalah pidana dan pemidanaan dalam sejarah selalu mengalami perubahan. Keberadaannya banyak diperdebatkan oleh para ahli. Bila disimak dari sudut perkembangan masyarakat manusia perubahan itu adalah wajar, karena manusia akan selalu berupaya untuk memperbaharui tentang suatu hal demi meningkatkan kesejahteraannya dengan mendasarkan diri pada pengalamannya di masa lampau. Sebagaimana diketahui bahwa Sistem Pemasyarakatan sebagai bagian pemidanaan yang dahulu dinamakan pemenjaraan yang berlaku dewasa ini, secara konseptual dan historis sangatlah berbeda dengan apa yang berlaku dalam sistem Kepenjaraan. Asas yang dianut system Pemasyarakatan dewasa ini menempatkan tahanan, narapidana, anak negara dan klien pemasyarakatan sebagai subyek dan dipandang sebagai pribadi dan warga negara biasa serta dihadapi bukan dengan latar belakang pembalasan tetapi dengan pembinaan dan bimbingan. 
Perbedaan kedua sistem tersebut, memberi implikasi pada perbedaan dalam cara-cara pembinaan dan bimbingan yang dilakukan, disebabkan perbedaan tujuan yang ingin dicapai.

Lembaga pemasyarakata merupakan tempat kegiatan untuk melakukan pembinaan masyarakat berdasarkan sistem, kelembagaan dan cara pembinaan yang merupakan bagian akhir dari sistem pemidanaan dalam tata cara peradilan pidana. Karena mereka telah melakukan kejahatan atau pelanggaran.

Pemikiran Bangsa Indonesia mengenai fungsi pemidanaan tidak sekedar pada aspek penjeraan saja tetapi juga merupakan suatu rehabilitasi dan reinteragrasi sosial telah melahirkan suatu sistem pembinaan terhadap pelanggar hukum yang dikenai sebagai sistem pemasyarakatan. Secara filosofi pemasyarakatan adalah suatu sistem pemidanaan yang sudah jauh meniggalkan sistem pembalasan, penjeraan dan resosialisasi. Dengan kata lain pemidanaan tidak ditujukan untuk membuat derita sebagai bentuk pembalasan, tidak ditujukan untuk membuat jera dengan penderitaan, juga tidak mengamsusikan terpidana sebagai seseorang yang kurang sosialisasinya.

Pemasyarakatan sejalan dengan filosofi reintergrasi sosial yang beramsusi kejahatan adalah konflik yang terjadi antar terpidana dengan masyarakat. Sehingga pemidanaan ditujukan untuk memulihkan konflik atau menyatukan kembali terpidana dengan masyarakatnya (reintragrasi).

Tujuan narapidana dimasukan ke lembaga pemasyarakatan, disamping memberikan rasa lega terhadap korban juga memberikan rasa lega di masyarakat, caranya yaitu dengan memberikan mereka pembinaan kemandirian maupun 2 kepribadian. Selama mengalami pemidanaan narapidana harus dikenalkan dengan masyarakat dan tidak boleh diasingkan. Narapidana diayomi dengan memberikan bekal hidup sebagai warga negara yang berguna dalam masyarakat. Tujuan diberikan pemidanaan adalah satu bagian dari rehabilitasi watak dan perilaku para narapidana, selama mengalami hukumannya narapidana mendapatkan bimbingan dan didikan yang berdasarkan Pancasila. Narapidana harus kembali ke masyarakat sebagai warga negara yang berguna dan sebisa mungkin tidak terbelakang, perlu diusahakan agar narapidana mempunyai mata pencaharian. Dalam pelaksanaan pembinaan perilaku narapidana di lembaga pemasyarakatan memiliki tantang bagi petugas pemasyarakatan di Kabupaten Sumenep, mereka memiliki tanggung jawab yang sangat besar untuk menjadikan cita-cita pemasyarakatan sebagai perwujudan keadilan dan pengadilan sebagaimana dicanangkan dalam konfrensi Lembang 1964 (Abdulmundzir, www. lapaslangsa. 
co. cc. diunduh 6 Januari 2013). Di sisi lain semua petugas mempunyai keterbatasan SDM dan kemampuan yang terbatas maka mereka bekerjasama dengan Pondok Pesantren, DIKNAS, dan lembagalembaga lain yang bersangkutan dengan pemasyarakatan.

Secara garis besar tugas pemidanaan ada dua faktor yaitu : pemberian hukuman (punishment) dan pemberian pembinaan (treatment). Artinya di dalam suatu pemberian pembinaan tersirat suatu pemberian hukuman, sistem pemasyarakatan yang baik tidak meninggalkan kedua unsur tersebut. Tindakan kriminal adalah salah satu fenomena yang komplek dan sering ditemui 3 didalam kehidupan masyarakat.

Oleh sebab itu dapat ditemukan berbagai jenis kejahatan, motif maupun perilaku kejahatan itu sendiri. Kejahatan dapat dibagi dari jenis yang ringan (Tipiring) misalnya pelanggaran lalu lintas sampai dengan jenis kejahatan yang berat misalnya perampokan dengan penganiyaan, pemerkosaan, dan pembunuhan. Selain jenis kejahatan yang beragam motif yang melatar belakangi beragam pula.

Motif kejahatan dilatar belakangi faktor kemiskinan, seseorang melakukan kejahatan karena adanya dorongan untuk memenuhi kebutuhan sehari-hari, sampai kejahatan yang teorganisir yaitu sekelompok orang yang melakukan kejahatan secara profesional misalnya korupsi kelas kakap, sindikat pengedar narkoba, penyeludupan barang mewah dan lain sebagainya, kejahatan dapat dilakukan oleh siapa saja bisa pria wanita maupun anak-anak dengan berbagai latar belakang. Di sinilah peran-peran petugas lembaga pemasyarakatan dibutuhkan untuk membimbing para narapidana agar tidak kembali mengulangi perbuatan yang sama, maka peran aktif petugas pemasyarakatan sangatlah dibutuhkan bagi para narapidana agar tidak menjadi residivis, mereka kembali ke masyarakat agar menjadi manusia yang lebih baik dan diterima kembali ke masyarakat.

Dari masalah-masalah di atas maka peneliti bermaksud untuk melakukan sosialisasi dengan judul "Pelaksanaan Pembinaan Narapidana di Rumah Tahanan Negara Klas IIB Kabupaten Sumenep". Selain permasalahan di atas sosialisasi ini juga dilatarbelakangi oleh dua alasan yaitu: alasan subjektif, dimana lokasi sosialisasi ini dekat dengan tempat tinggal penulis sehingga bisa menghemat biaya dan alasan objektif, yaitu dimana biasanya pembinaan narapidana dilaksanakan di Lembaga Pemasyarakatan tapi kali ini dilaksanakan di Rumah Tahanan, oleh karena itulah peneliti ingin mengkaji lebih dalam hal tersebut. 
FAKULTAS HUKUM UNIVERSITAS WIRARAJA SUMENEP - MADURA

\section{PENUTUP}

Sistem pemasyarakatan bertujuan mengembalikan narapidana kedalam lingkungan masyarakat sebagai warga yang baik.. Pelaksanaan kegiatan kerja dilaksanakan dengan membaurkan narapidana dengan lingkungan masyarakat. Kegiatan pembinaan diupayakan dengan memberikan kesempatan yang luas bagi masyarakat dalam pembinaan (metode community based corrections). Hal ini terlihat melalui pelaksanaan program pembinaan serta adanya pembinaan dengan metode community based corrections yang dapat diterima dengan baik dan memberikan manfaat kepada narapidana. Lembaga pemasyarakatan perlu berbenah diri mengenai sistemnya

\section{DAFTAR PUSTAKA}

Cipta. Daroeso, Bambang. 1986. Dasar dan Konsep Pendidikan Moral Pancasila. Semarang.

Aneka Ilmu. Harsono Hs. 1995. Sistem Baru Pembinaan Narapidana. Jakarta. Djambatan.
Kurtines dan William M. 1992. Moralitas Perilaku Moral dan Perkembangan Moral. Jakarta. UI

Muladi. 1986. Teori-Teori Dan Kebijakan Pidana. Bandung. PT. Alumni. Moeljatno. 2000.

Asas-Asas Hukum Pidana. Jakarta. Rineka Cipta. Moleong, Lexy j. 2009. Metodologi Penelitian Kualitatif. Bandung. PT. Remaja Rosdakarya.

\section{Peraturan Perundang-undangan :}

Undang-Undang Nomor 12 Tahun 1995 tentang Pemasyarakatan

keputusan menteri kehakiman Republik Indonesia Nomor : M. 02PK.04.10 tahun 1990 tentang pola pembinaan narapidana atau tahanan 